\title{
Churg-Strauss Syndrome Accompanied by Acute Coronary Syndrome in the Absence of Coronary Atherosclerosis
}

\author{
Koroner Ateroskleroz Olmaksızın Akut Koroner Sendrom ile Birlikte Seyreden \\ Churg-Strauss Sendromu
}

\author{
Demet Menekşe GEREDE, ${ }^{1}$ Orhan KÜÇÜKŞAHİN, ${ }^{2}$ Elif Ezgi ÜSTÜN, ${ }^{1}$ Kerim ESENBOĞA, ${ }^{1}$ Sibel TURHAN ${ }^{1}$ \\ ${ }^{1}$ Department of Cardiology, Medical Faculty of Ankara University, Ankara, Turkey \\ ${ }^{2}$ Department of Rheumatology, Medical Faculty of Ankara University, Ankara, Turkey
}

\begin{abstract}
Herein, we report a 35-year-old female case who was admitted to our emergency department with chest pain along with a past history of asthma and pleural effusion. Her laboratory findings revealed high levels of cardiac biomarkers [troponin I (Tnl) and creatine kinase-MB isoenzyme (CK-MB)] without significant ST segment and $\mathrm{T}$ wave (ST-T) changes in the electrocardiogram. Transthoracic echocardiography showed hypokinesis of the anterior wall with an ejection fraction of $48 \%$ and minimal pericardial effusion. Coronary arteriography revealed a distally occluded left anterior descending coronary artery. Churg-Strauss syndrome with acute coronary syndrome was diagnosed. The patient was administered systemic corticosteroid therapy. Our patient subsequently made an uneventful recovery.
\end{abstract}

Key words: Acute coronary syndrome; Churg-Strauss syndrome; elevated cardiac biomarker; vasculitis.

Churg-Strauss syndrome (CSS) is defined by the American College of Rheumatology (ACR) as eosinophilic vasculitis in addition to one or more of the following: asthmatic airway obstruction, a differential leukocyte count with more than $10 \%$ eosinophils, migratory or transient pulmonary infiltrates, sinusitis and mononeuropathy, or polyneuropathy. ${ }^{[1]}$ ChurgStrauss syndrome can lead to cardiac involvement in up to $60 \%$ of patients, and this is a leading
Bu yazıda astım ve plevral efüzyon öyküsü ve göğüs ağrısı ile acil servisimize başvuran 35 yaşında bir kadın olgu sunuldu. Laboratuvar bulgularında, elektrokardiyografide ST segment ve $T$ dalgasında (ST-T) anlamlı bir değişiklik olmaksızın, kardiyak biyobelirteç [(troponin I (Tnl) ve kreatin kinaz-MB izoenzim (CK-MB)] düzeylerinde artış görüldü. Transtorasik ekokardiyografide \%48 ejeksiyon fraksiyonu ile ön duvarda hipokinezi ve minimal perikardiyal efüzyon izlendi. Koroner anjiyografide ise, sol ön inen koroner arter distalinde tıkanıklık saptandı. Akut koroner sendromla birlikte seyreden ChurgStrauss syndrome tanısı konuldu. Hastaya sistemik kortikosteroid tedavisi başlandı. Tedaviyi takiben herhangi bir olay görülmeden iyileşme gözlendi.

Anahtar sözcükler: Akut koroner sendrom; Churg-Strauss sendromu; yükselmiş kardiyak belirteç; vaskülit.

cause of mortality that accounts for approximately one-half of the deaths associated with CSS. ${ }^{[1,2]}$ The cardiac problems associated with patients with CSS include a wide range of pathologies such as congestive heart failure, pericardial effusions, myocarditis, and intracardiac thrombosis. Myocardial infarction (MI) is also a rare clinical manifestation ${ }^{[3,4]}$ and should be kept in mind as a differential diagnosis in CSS cases with an appropriate clinical picture. Herein, we

\footnotetext{
Received: April 20, 2013 Accepted: May 16, 2013

Correspondence: Demet Menekşe Gerede, M.D. Ankara Üniversitesi Tıp Fakültesi Kardiyoloji Anabilim Dalı, 06100 Sıhhiye, Ankara, Turkey. Tel: +90 312 - 2367451 e-mail: drmeneksegerede@yahoo.com 
present the case of a patient with CSS accompanied by pericarditis and acute coronary syndrome (ACS).

\section{CASE REPORT}

A 35-year-old woman presented to the emergency department with approximately a one-month history of chest pain and shortness of breath; however, the frequency of her symptoms had increased over the previous 10 days. In addition, her chest pain occurred both at rest and during exercise.

The patient's past medical history revealed asthma and recurrent pleural effusion of an unknown origin. After an initial assessment by the pulmonary medicine department to investigate the etiology of the pleural effusion, this fluid was analyzed for signs of tuberculosis (TB), even though the patient had no major risk factors that would have exposed her to this disease. The test results were negative.

High levels of creatine kinase MB isoenzyme (CK-MB) and troponin I (TnI) (TnI $3.405 \mathrm{ng} / \mathrm{mL}$ with a reference value of $<0.06 \mathrm{ng} / \mathrm{mL}$; CK-MB $19.4 \mathrm{ng} / \mathrm{mL}$ with a reference value of $0.6-6.3 \mathrm{ng} / \mathrm{mL}$ ) were identified on an electrocardiogram (ECG) performed at admission, but no significant ST-segment or T wave (ST-T) changes were found. However, a complete blood count (CBC) revealed leukocytosis with eosinophilia (47.1\%).
The patient was admitted to the coronary care unit with a prediagnosis of myopericarditis. Although the disease presented with the clinical findings of ACS, it was not considered to be the primary diagnosis due to the patient's youth and absence of risk factors for atherosclerotic coronary disease. Myopericarditis was suspected because of the TnI elevation in the laboratory results, hypokinesis of the anterior wall, and minimal pericardial effusion identified via echocardiography. Subsequently, the patient was treatment with colchicine and high-dose aspirin.

During the clinical follow-up period, the patient's ECG showed dynamic anterior ST-T changes in the precordial derivations (Figure 1), and repeat measurements of these markers revealed a typical course of ACS that featured a relevant rise and fall in TnI. Therefore, the patient underwent coronary angiography which revealed a distally occluded left anterior descending coronary artery (Figure 2). Percutaneous transluminal coronary angioplasty was performed on the occluded site, and because of the thrombotic view of the lesion with a remnant of $30 \%$ stenosis accompanied by thrombolysis in myocardial infarction (TIMI) three flow, medical therapy with tirofiban infusion was prescribed for up to a period of 24 hours instead of stent implantation.

Consultations were then held with the pulmonary medicine and rheumatology departments regarding

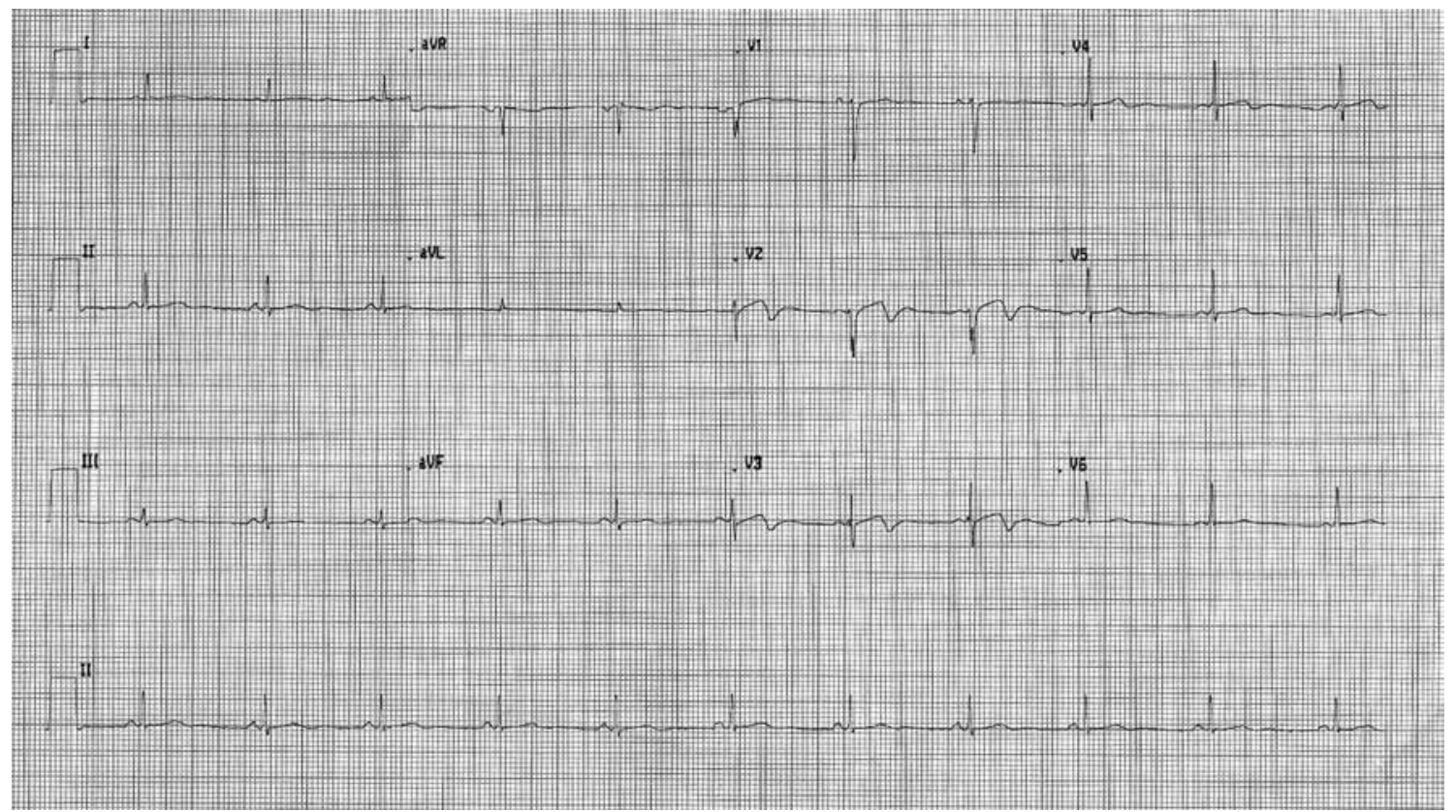

Figure 1. During clinical follow-up, the patient's electrocardiogram showed dynamic anterior ST-T changes in the precordial derivations. 


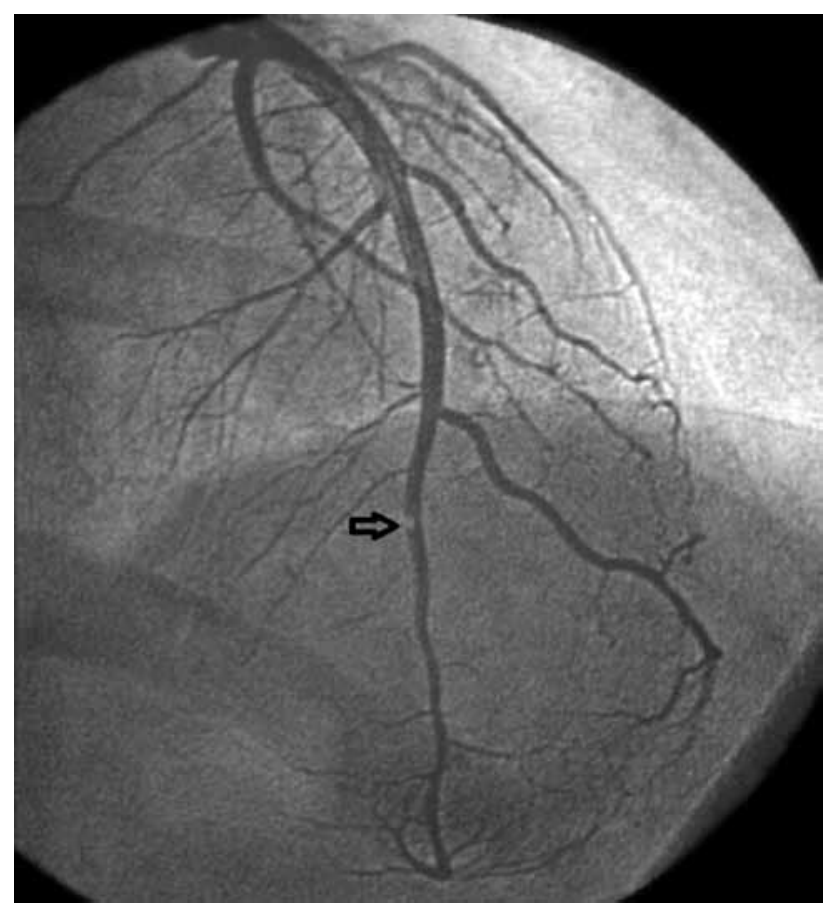

Figure 2. This figure shows the left anterior descending artery via coronary angiography. The thrombotic lesion can be seen in the distal left anterior descending artery.

the eosinophilia identified in the CBC, pulmonary opacities revealed via chest X-ray, and the patient's past history of asthma (Figure 3). Furthermore, cranial computed tomography (CT) was performed on the day after the angiography which showed neurological involvement or paranasal sinus abnormality with a prediagnosis of CSS. The results of the cranial CT were also consistent with chronic sinusitis. The presence of asthma, hypereosinophilia of $>10 \%$, chronic sinusitis, and pulmonary opacities represent four of the six ACR criteria required for the diagnosis of CCS. ${ }^{[5]}$ Our patient tested negative for anti-nuclear antibodies (ANAs), anti-double stranded DNA (antidsDNA), extractable nuclear antigens (ENAs) and anti-neutrophil cytoplasmic antibodies (ANCAs). The corticosteroid methylprednisolone at an initial dosage of $80 \mathrm{mg}$ per day $(1 \mathrm{mg} / \mathrm{kg} / \mathrm{d})$ was prescribed after the termination of the tirofiban infusion. Afterwards, the patient's eosinophil levels in the CBC decreased to normal ranges, and symptomatic relief was completely provided. Control coronary angiography was performed one week later, and the thrombotic lesions had disappeared (Figure 4). In addition, chest radiographs showed complete resolution of the opacities (Figure 5). After two more weeks,

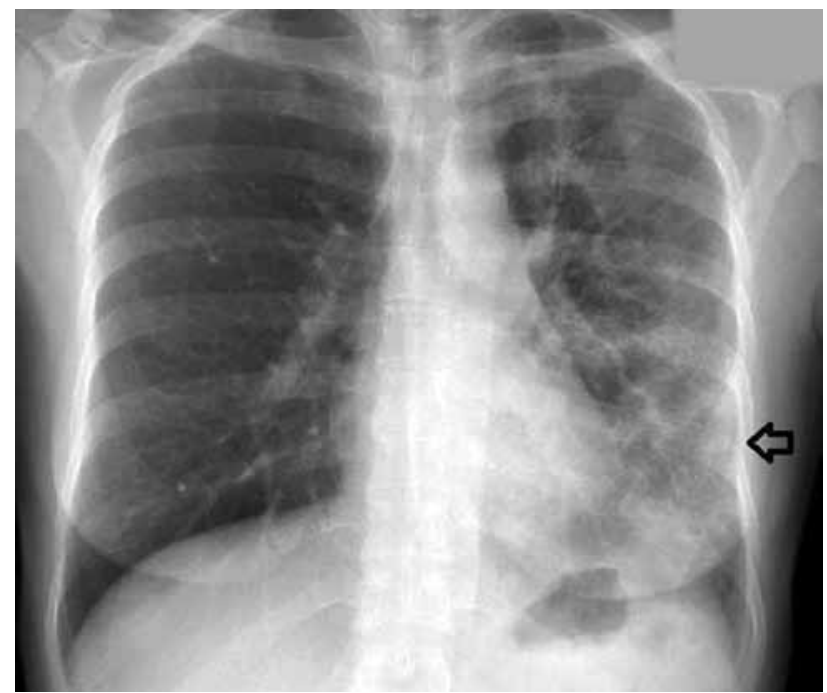

Figure 3. The initial posteroanterior pulmonary radiograph revealed the presence of pulmonary opacities.

control echocardiography was performed revealing a normal morphology of the ventricles without any segmental wall motion abnormalities. Furthermore, the pericardial fluid had also disappeared.

\section{DISCUSSION}

Churg-Strauss syndrome is a systemic, necrotizing vasculitis that affects small- to medium-sized

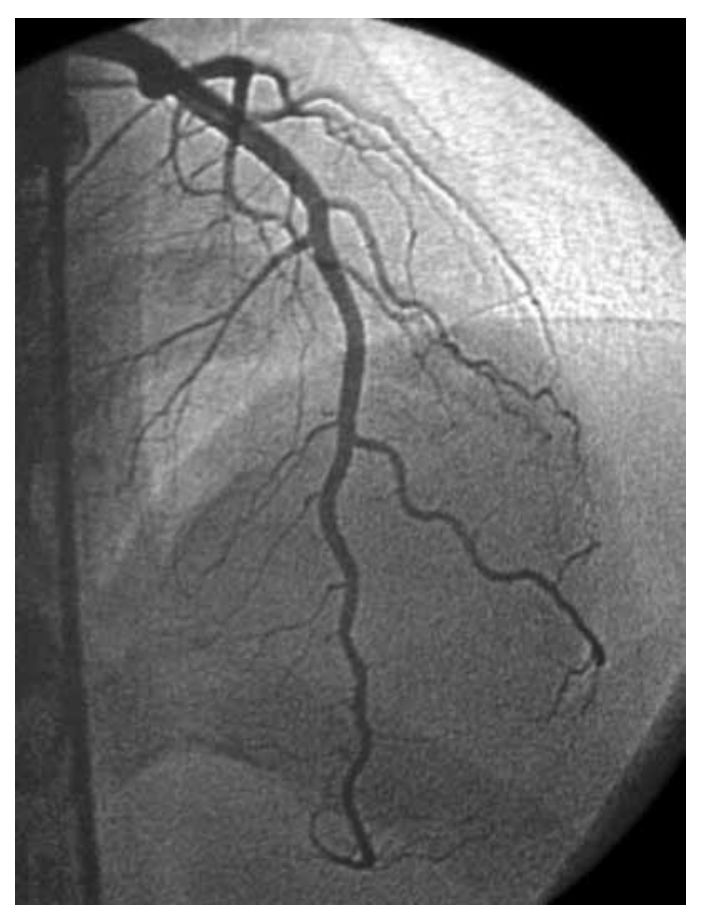

Figure 4. Control coronary angiography after one week showing no thrombotic lesions. 


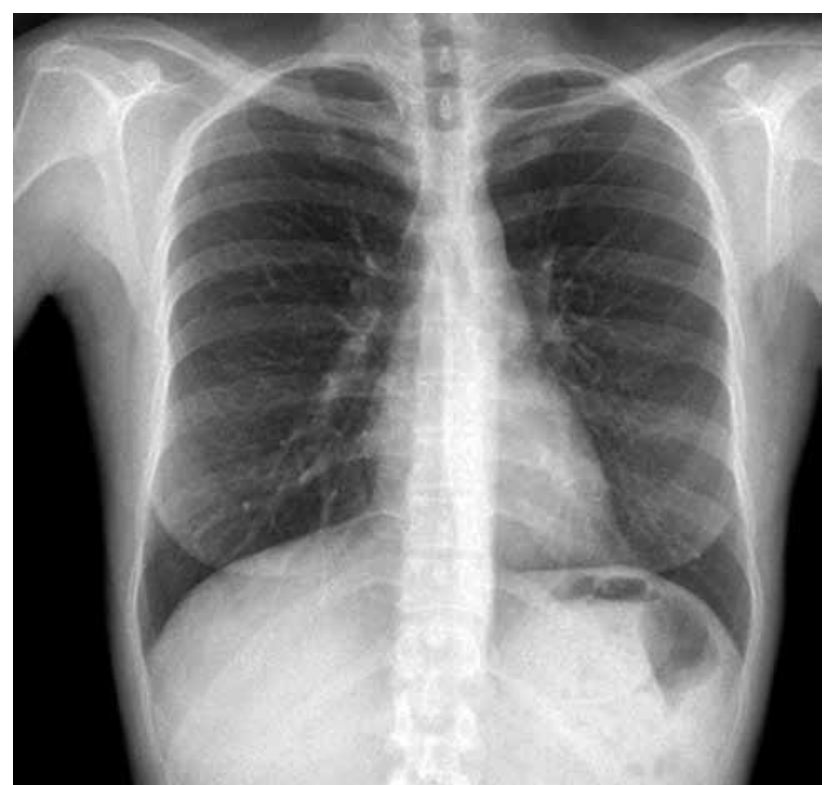

Figure 5. Post-treatment chest X-ray revealing no opacities.

vessels. ${ }^{[2,3]}$ Cardiac involvement occurs frequently in CSS, resulting in significant morbidity and mortality. ${ }^{[2]}$ Coronary arteritis is generally considered to be a part of systemic vasculitis, but on rare occasions, it can be an isolated manifestation of CSS that causes MI. ${ }^{[2]}$ The overall prognosis for CSS is good; however, diffuse organ involvement, particularly in connection with the cardiovascular system, is associated with a poorer prognosis and increases mortality. In addition, central nervous system involvement may rarely occur with the same unfavorable outcomes. ${ }^{[3]}$

Although cardiac involvement was not mentioned in the 1990 ACR criteria for CSS, it is a common clinical manifestation that accounts for approximately one-half of all deaths attributable to this disorder. ${ }^{[1]}$ Coronary artery vasospasm is another rare manifestation associated with CSS. However, in the literature, coronary vasculitis associated with CSS most often presents with vasospasm, whereas coronary thrombosis was observed in our case. ${ }^{[1,4]}$

Since systemic inflammation is believed to play a crucial role in endothelial damage, CSS is not the only disorder with "atypical" coronary pathology. Other rheumatic disorders can also present with coronary vasculitis, which can lead to coronary spasms and/or thrombosis. ${ }^{[6,7]}$

Immunosuppressive treatment with corticosteroids can result in the improvement of impaired cardiac contractility and resolution of pericardial effusions, and this is exactly what happened with our patient after the control echocardiography revealed normal morphology of the ventricles without segmental wall motion abnormality along with no pericardial effusion.

In addition, as with our case, patients with cardiac involvement are less likely to test positive for ANCA. ${ }^{[3]}$

\section{Conclusion}

Our patient, who was diagnosed with CSS accompanied by ACS, recovered completely after medical therapy with corticosteroids. In contrast, coronary vasculopathy generally shows regression after corticosteroid treatment. Whether the thrombotic view was recovered secondarily to the tirofiban infusion or the treatment with corticosteroids remains uncertain. As a result our findings, CSS should be considered, especially in young female patients diagnosed with ACS.

\section{Declaration of conflicting interests}

The authors declared no conflicts of interest with respect to the authorship and/or publication of this article.

\section{Funding}

The authors received no financial support for the research and/or authorship of this article.

\section{REFERENCES}

1. Rigamonti F, De Benedetti E, Letovanec I, Rosset A, Chizzolini C. Cardiac involvement in Churg-Strauss syndrome mimicking acute coronary syndrome. Swiss Med Wkly 2012;142:w13543.

2. Smedema JP, van Paassen P, van Kroonenburgh MJ, Snoep G, Crijns HJ, Tervaert JW. Cardiac involvement of Churg Strauss syndrome demonstrated by magnetic resonance imaging. Clin Exp Rheumatol 2004;22:S75-8.

3. Wagner AD, Meyer GP, Rihl M, Rathmann A, Wittkop $\mathrm{U}$, Zeidler $\mathrm{H}$, et al. Acute coronary syndrome associated with Churg-Strauss syndrome. Vasc Health Risk Manag 2007;3:775-9.

4. Tanaka M, Mise N, Kurita N, Suzuki T, Hara K, Fujii A, et al. A case of Churg-Strauss syndrome with necrotizing crescentic glomerulonephritis accompanied by acute coronary syndrome due to vasospasm. Am J Kidney Dis 2010;56:e5-9.

5. Masi AT, Hunder GG, Lie JT, Michel BA, Bloch DA, Arend WP, et al. The American College of Rheumatology 1990 criteria for the classification of Churg-Strauss syndrome (allergic granulomatosis and angiitis). Arthritis Rheum 1990;33:1094-100.

6. Gasparyan AY, Cocco G, Pandolfi S. Cardiac complications in rheumatoid arthritis in the absence of occlusive coronary pathology. Rheumatol Int 2012;32:461-4.

7. Cocco G, Gasparyan AY. Myocardial ischemia in Wegener's granulomatosis: coronary atherosclerosis versus vasculitis. Open Cardiovasc Med J 2010 23;4:57-62. 